\title{
An Economic Assessment of Mountain Pine Beetle Timber Salvage in the West
}

\author{
Jeffrey P. Prestemon, Karen L. Abt, Kevin M. Potter, and Frank H. Koch
}

The mountain pine beetle has killed lodgepole pine and other species of pines in the western United States in an ongoing epidemic. The most heavily affected states are in the interior West: Colorado, Idaho, Montana, and Wyoming, with smaller losses elsewhere. Timber salvage is one response to the epidemic, which could generate revenues for affected landowners and provide wood to forest product manufacturers and, potentially, energy producers. Salvage is occurring, but policymakers have advocated greater rates of such timber removals. To estimate total costs and revenues from salvage and thereby illuminate the economic dimensions of greater salvage removals, we simulated alternative salvage intensity levels on national forests and on other public and private lands where dead standing timber could be potentially recovered and entered into product markets. Data indicate that 19.7 billion cubic feet of standing dead timber are potentially available for salvage, distributed across 20.3 million acres in 12 western states. Simulations on national forests and on lands under other ownerships indicate that positive net revenues (revenues minus costs) could be produced in states with active timber markets on the West Coast and in the northern Rockies, where timber prices would be less depressed by the introduction of large salvage volumes. The central Rocky Mountain states of Colorado, Utah, and Wyoming, which have the largest percentage volume and acreage impacts from salvable standing dead timber, would not generate profitable timber salvage. Simulations of a hypothetical doubling of demand in Colorado and Montana leave Colorado with smaller losses and Montana with larger gains.

Keywords: insects, wood products, markets, epidemic, spatial equilibrium

$\mathrm{P}$ ine forests of the western United States and Canada have been experiencing high rates of mortality, in part due to an epidemic outbreak of mountain pine beetle (MPB; Dendroctonus ponderosae; Chapman et al. 2012, Meddens et al. 2012). Other contributors to higher rates of timber mortality include wildfires and a variety of less well-known insects and diseases. Few options are available to timberland managers and landowners to prevent mortality, but the visual impact, potentially increased wildfire threat, and the hazard of falling dead trees can be partially addressed by salvaging damaged timber. Indeed, Canadian land managers have embarked on widespread timber salvage as a way of retrieving some value before complete wood decay and sometimes to encourage the regeneration of valuable and productive new forests (Patriquin et al. 2007, Vysea et al. 2009). US national forests are also selling salvaged timber; $14 \%$ of all timber sold in fiscal year 2011 was recorded as salvage (USDA Forest Service 2011a). The USDA Forest Service (2011b) has developed the Western Bark Beetle Strategy that lays out priorities and details how increased salvage rates might be achieved.

While policymakers and forest managers in the United States have proposed embarking on accelerated rates of salvage on affected lands, such increases require concerted efforts by private landowners to seek out new markets or by public landowners to prioritize management in a way that favors salvage. Complicating the prioritization are weak timber product markets, which could absorb some of the timber removed but that have contracted since the mid-2000s.
The number of mills and the total lumber output across the West have declined broadly (Spelter et al. 2009), constraining the potential financial benefits of salvage.

Nevertheless, it is plausible that opportunities for positive net revenue or break-even salvage revenue operations exist in certain locations and among particular owner groups in MPB-affected areas of the West. We define net revenues as the revenues received at the mill gate less the costs of harvesting, transportation, and administration. The objective of this study was to identify these opportunities using an economic assessment model that accounts for costs of salvage, the impact of mortality on timber quality, and the effects of salvage on market prices across the West. Our study estimated potential salvage volumes, costs, and revenues resulting from a set of alternative programs that would encourage salvage of standing dead timber; results are summarized by state and by owner groups.

\section{Methods}

In this study, we employ the Economics of Biomass Removals (EBR) model to quantify how the costs and revenues of salvage focused on timberland in the West would be distributed across states and over time. The EBR model was originally designed (Abt and Prestemon 2006, Huggett et al. 2008, Prestemon et al. 2008) to evaluate both the costs and the timber market impacts of alternative programs to reduce hazardous wildfire fuels across the US West and South. Based on this research, the EBR model has been used to evaluate the timber product output implications of hazardous fuel

\footnotetext{
Manuscript received September 27, 2012; accepted March 6, 2013. http://dx.doi.org/10.5849/wjaf.12-032.
}

Jeffrey P. Prestemon (jprestemon@fs.fed.us), USDA Forest Service, Southern Research Station, Research Triangle Park, NC. Karen L. Abt (kabt@fs.fed.us), USDA Forest Service, Southern Research Station. Kevin M. Potter (kevinpotter@fs.fed.us), North Carolina State University. Frank H. Koch (fhkoch@fs.fed.us), USDA Forest Service, Southern Research Station. We are grateful to Frederick W. Cubbage, Linda L. Langner, and Kurt Niquidet for their thoughtful reviews of the manuscript and to Frank Sapio and Mark Ambrose for helpful discussions regarding data used in this study. This work was supported in part through Research Joint Venture Agreements 10-JV-11330146-064 and 11-JV-11330146-090 between the USDA Forest Service, Southern Research Station, and North Carolina State University. 
reduction treatments in the West (Barbour et al. 2008), to quantify the jobs and biomass production impacts of these treatments (Abt et al. 2011), and to evaluate whether wildfire hazard reduction treatments yield overall net benefits on timberlands of the West (Prestemon et al. 2012).

\section{Model}

The EBR model is a multiyear two-stage goal and spatial equilibrium program, and it was modified for this study to model the economic feasibility of salvage of dead timber on public and private lands in the West. Although details of the model, including its mathematical formulation, are provided in Prestemon et al. (2008, 2012), describing the modeling framework is important for understanding the current study. EBR can be run for a single year or multiple years, treating timberland (salvaging standing dead trees, in this study) each year according to a predefined set of objectives. After each simulated year, timber inventory data are updated, with the transition to the next year defined by stand growth, new mortality available for salvage, and the volumes removed in the previous year's solution.

The first stage of this revised version of the EBR model is a goal program that selects locations in the West to salvage timber by maximizing a goal-weighted sum of salvage volumes, subject to maximum and minimum harvest constraints, a feasible forest product market solution, and an assumed maximum amount of expenditures available to harvest and transport salvage timber to mills. The fundamental unit of information about timber volumes (salvage, nonsalvage) to which the goal weights are applied in the EBR model is the Forest Inventory and Analysis (FIA) plot. To allow for a reasonably fast solution, plot-level information is summed to a spatial and ownership aggregate. Plot-level information includes the average distance to the nearest five sawmills (which consume sawlogs) and the average distance to the two nearest pulp or pole mills (consuming the smaller diameter portions of trees in the stand). Other variables reported or calculated at the plot level include volumes by product category (merchantable live and dead sawlogs and pulpwood) and tree groups-ponderosa pine (Pinus ponderosa and $P$. lambertiana), lodgepole pine ( $P$. contorta), southern pine (especially $P$. echinata, $P$. palustris, $P$. elliottii, $P$. taeda), other softwood, and hardwood; ownership (national forest, other public, private); LANDFIRE Map Zone (LANDFIRE 2010); the harvest cost for removing live or dead volumes; and, an administration cost of $\$ 200$ /acre for public and $\$ 100$ /acre for private timberland salvage ${ }^{1}$. In this study, we aggregated plot-level information up to the map zone for each ownership group for each of the 12 western states in the contiguous United States. LANDFIRE map zones ${ }^{2}$ are generalized geographical units with similar ecological and biophysical characteristics. The 50 United States contain 79 such zones, which span state boundaries. The 12 states in this study contain 29 map zones, although the area and total standing timber volume found in these zones vary widely. Therefore, the basic modeling units, from which treatment volumes could be obtained in the first stage, are the map zone-ownership aggregates in each of the 12 western states. Depending on the simulation implemented (more information on the simulations is provided in the next section), treatment volumes selected in the first stage could be obtained from parts or all of one map zone-ownership aggregate. Harvest costs, timber volume information by species and live or dead status, and transport costs were expanded to the map zone-ownership aggregate using an area expansion factor. The result is a summary of the total area of stands of salvable timber in each map zone-ownership aggregate and for each of these the weighted average volumes per acre by species by product by live and salvable dead, weighted average transport distances to mills, and the weighted average harvest cost. Finally, the goal weights placed on map zone-ownership aggregates were the presolution net revenues of timber salvage removed; only dead standing salvable timber could be removed. The net revenue in the first stage is defined as the premarket solution value of salvaged sawlogs and pulpwood by species: the delivered volume multiplied by each product's respective market price times a salvage discount factor minus the total stand's harvest and transport costs per acre. As defined, net revenues can be negative. In effect, the EBR model had an ordered preference for salvage of timberlands according to their per acre net revenues.

The second stage of the EBR model maximizes, subject to the salvage volumes selected in the first stage in each map zone-ownership aggregate location, the sum of timber product producer and consumer surplus minus transport costs for harvested volumes of both salvage and nonsalvage timber moving across state and international borders (Samuelson 1952, Takayama and Judge 1964). The basic timber product market modeling unit-two levels of aggregation higher than the map zone-ownership-in which equilibrium product prices by species group are obtained, is the state. Trade restrictions that ban exports of roundwood flowing from western US federal lands are imposed. State level maximum processed volumes are determined by state-level mill capacities that act as a physical limit on the volume of timber products that can be processed within the state without new processing capacity being added. We allow these capacities to be exceeded by up to $30 \%$ to reflect the possibility of adding shifts to existing mills (Prestemon et al. 2008). The EBR model also allows for the siting of new processing capacity, although this is not implemented endogenously (as in Ince et al. 2008). The second stage optimal solution is a set of market equilibrium product prices, and the volumes by species of timber salvaged (and harvested nonsalvage) produced in each state, consumed at mills in each location, and traded across state and international borders.

The result of a set of a multiyear simulations run by the EBR model is an assessment of the net revenue impacts of salvage on national forests, other public, and private lands in the 12 contiguous western US states. In this study, we further summarize the results in terms of salvage costs and salvage revenues by state and ownership group. While not reported in this study, model outputs also include prices and economic welfare changes resulting from changes in salvage. Such changes may be of interest when seeking to quantify how salvage negatively impacts the welfare of owners of nonsalvage timber (e.g., Prestemon and Holmes 2004, Prestemon et al. 2006). It is worth noting, however, that the net revenues generated from salvage on private lands are gross, before taxes. By varying an assumption on the magnitude of a government program to salvage national forest, other public, or private timber, we describe how the geographical focus of a government-subsidized or national forest salvage program might shift across states in the West. By carrying out a "what-if" scenario that tests the effects of a doubling of the total mill capacity in two states of the West that have been heavily affected by the mountain pine beetle-Montana and Colorado-we examine how efforts to encourage or subsidize the consumption of salvaged timber would affect net revenues of salvage obtained by timberland owners (public and private). Finally, by altering our assumption about the regular accumulation of additional standing volumes of 
Table 1. USDA Forest Service Forest Inventory and Analysis (FIA) survey years, by state.

\begin{tabular}{lc}
\hline \multicolumn{1}{c}{ State } & Survey years $^{1}$ \\
\hline Arizona & $2001-2009$ \\
California & $2001-2009$ \\
Colorado & $2002-2009$ \\
Idaho & $2004-2009$ \\
Montana & $2003-2009$ \\
Nevada & $2004-2005^{2}$ \\
New Mexico & $1999^{2}$ \\
Oregon & $2001-2009$ \\
South Dakota & $2005-2009$ \\
Utah & $2000-2009$ \\
Washington & $2002-2009$ \\
Wyoming & $2000^{2}$ \\
\hline
\end{tabular}

${ }^{1}$ Annualized surveys conducted as specified in Bechtold and Patterson (2005).

${ }^{2}$ Periodic survey data used for these states where annualized surveys are incomplete.

salvage timber-from a set annual percentage increase to no more accumulation of standing dead timber-we assess how the spatial targeting of salvage efforts on national forests and other lands would be affected.

\section{Data}

Timber inventory data from Forest Service FIA surveys were assembled for all timberland that is open to harvest and not protected by easements or otherwise set aside for conservation purposes in 12 western US states. The survey years used for each state are reported in Table 1. Data are summarized by owner group (all owners and national forests only), by species group (ponderosa pine, lodgepole pine, other softwood, and hardwood), and by product (sawtimber-representing the cubic foot volume in the sawlog portion of the tree-and pulpwood-representing all other growing stock volume in the tree). Trees coded as standing dead had only total volume measured, so allocations to sawtimber and pulpwood were assumed to be identical to the overall share of sawtimber and pulpwood found in the live trees on the plot, if any. Forested plots without live trees were assumed to have a sawtimber share of standing volume equal to 0.8 . Further information on FIA methods can be found in Bechtold and Patterson (2005).

While initial interest was in modeling salvage of only MPB-killed stands, the FIA data did not offer the option to restrict the volume and acreage data for dead timber based on the cause of mortality. While some information on MPB-affected forests in the West is available from aerial detection surveys, the data produced by these surveys (e.g., Backsen and Howell 2013) were not suitable for our study (see Meddens et al. 2012). Although modeling the salvage of timber killed by all causes is not the same as modeling the salvage of MPB-killed trees, salvage operations should be indifferent to the cause of mortality.

One advantage of employing FIA data is that plots are measured on a representative sample frame and, therefore, have a level of accuracy that provides greater confidence in simulated salvage programs. FIA plots have representative samples of species, sizes of trees, and site conditions, which allow for accurate assessments of both the materials that can be removed during salvage and the costs of removal of salvable timber.

Salvage volume adjustment factors were applied to the standing timber, with an assumption that the net salvable volume was $64 \%$ of the volume measured by FIA, which is based on regional averages from Fahey et al. (1986) and Lowell et al. (1992). This adjustment was needed to account for the higher degrade present in standing
Table 2. Scenarios for this study.

\begin{tabular}{|c|c|c|c|}
\hline Geography & Owner $^{1}$ & $\begin{array}{l}\text { Epidemic } \\
\text { continuing }\end{array}$ & $\begin{array}{l}\text { Processing } \\
\text { capacity }^{3}\end{array}$ \\
\hline Individual states & All owners & Yes & Current \\
\hline - & NF only & “ & “ \\
\hline Westwide & All owners & Yes & Current \\
\hline “ & " & No & “ \\
\hline “ & NF only & Yes & “ \\
\hline “ & “ & No & “ \\
\hline Colorado only and Montana only & All owners & Yes & Current \\
\hline “ & “ & “ & $2 \times$ pulpwood \\
\hline “ & “ & “ & $2 \times$ all \\
\hline “ & NF only & “ & Current \\
\hline “ & “ & “ & $2 \times$ pulpwood \\
\hline “ & “ & “ & $2 \times$ all \\
\hline
\end{tabular}

\footnotetext{
1 "NF" stands for national forests.

${ }^{2}$ A continuing epidemic is simulated by moving $2 \%$ of healthy timberland into salvable timberland each year. An ending epidemic is simulated by holding area of salvable timberland constant.

3 " $2 \times$ pulpwood" means that processing capacity doubles for mills processing small diameter materials (pulpwood). " $2 \times$ all" means that processing capacity doubles for mills processing sawtimber and mills processing small diameter materials (pulpwood). Average haul distances to these mills shrink by $30 \%$.
}

dead timber. The rate of degrade and volume losses to decay vary across climatic gradients in the western US, but we used a common degrade factor, which provided sufficient detail for this analysis. Lumber milling technology to extract greater volumes from beetlekilled timber is advancing, so the $64 \%$ might be considered conservative in the coming years for the United States. Nonetheless, we consider it a reasonable first approximation of the effect of beetle damage on merchantable wood volume and overall value.

Timberland classified as salvable in these simulations was required to have at least 300 cubic feet (cf) per acre (ac) of standing dead timber. We labeled this land as salvable timberland, and the volumes on this land as salvable volumes. We note here that available salvage volumes were lower on the private lands (a weighted average across these plots of $459 \mathrm{cf} / \mathrm{ac}$ ) compared to that available on national forests $(664 \mathrm{cf} / \mathrm{ac})$ or other public lands $(578 \mathrm{cf} / \mathrm{ac})$ evaluated in this study. Based on previous research (Abt and Prestemon 2006, Huggett et al. 2008, Prestemon et al. 2008), we assumed that timberland with less than $300 \mathrm{cf} / \mathrm{ac}$ of standing dead timber would not be profitable to harvest, as only standing dead timber from salvable stands is harvested. Frequently, a portion of the standing inventory in salvable stands is live (green), but our simulations assumed that the live timber was left unharvested. In effect, only stands in which $100 \%$ of the standing volume was dead received a final harvest (clearcut), while other stands received partial cuts. This assumption could be relaxed in future modeling but was maintained throughout the simulations reported here.

\section{Simulations}

Simulations were done for 10-year programs of salvage using 20 alternative program sizes, i.e., the overall scale of salvage operations across owner groups and landscapes (Table 2). In this paper, we use the term "program size" to refer to the scale of salvage operations across the owner group and states involved in each simulation. Sizes were measured by the total expenditures made (costs incurred) to harvest and transport the salvaged timber and to administer the salvage sales. Sizes of programs were varied to better understand the importance of market price impacts and the effects of processing capacity constraints in limiting the net revenues achieved from salvage. In reality, program size might refer to specific programs funded by the government to remove salvable timber from public 


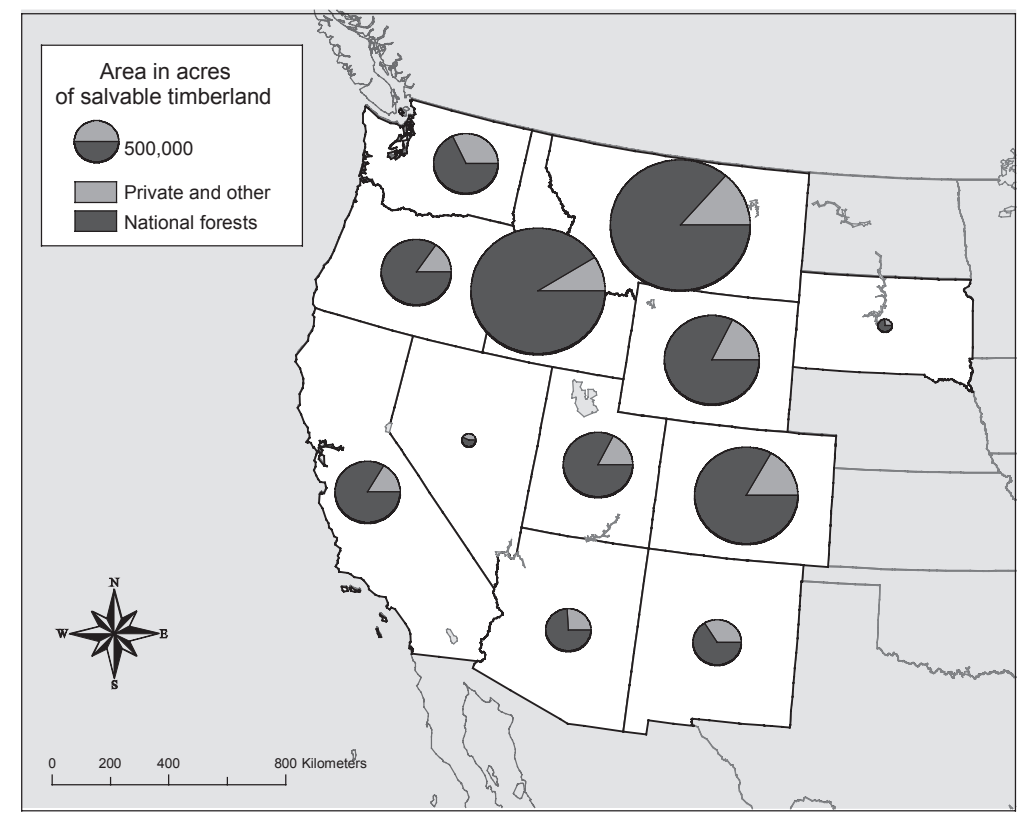

Figure 1. Area of timberland with salvable volumes by owner.

lands or to subsidize such salvage on private lands. To simulate the effect of a continuation of the current MPB epidemic, salvable timberland area was allowed to increase over time in most of our simulation scenarios. This increase was allowed only if the modeling unit (map zone-ownership aggregate in each state) had available timberland with less than $300 \mathrm{cf} / \mathrm{ac}$ (about 10.5 tons/ac) of standing dead timber (i.e., "healthy" timberland) from which to draw. If there was timberland from which to draw, then $2 \%$ of that timberland was assumed to die and move into the salvable inventory each year ${ }^{3}$. That is, in modeling units with healthy timberland available, by the end of the simulation run of 10 years (for each simulated program size), $20 \%$ of the healthy timberland in that unit was reclassified as dead but salvable in the model. We assumed the epidemic had ended in only two of the simulation scenarios (Table 2).

We also evaluated the effects that changes in mill capacities could have on the resulting salvage programs (Table 2). Such an increase in capacity may not be likely without government intervention, given today's low timber prices and uncertainty about long-run availability of timber salvage. However, this what-if scenario is a way to evaluate the impact of expanded timber product demand in each state that could occur under a plausible scenario in which state or federal governments offer subsidies to facilities that, for example, use wood to create energy. Mill capacities were assumed to double for two states (Colorado and Montana), where either (i) only pulpwood capacity was doubled (to reflect only an increase in capacity for small diameter timber), or (ii) both pulpwood and sawtimber capacity were doubled. We chose these two states because, while both have high proportions of salvable timber, their timber markets are fundamentally different: Montana has a large market for traditional timber products (lumber, posts, poles, pulpwood), while Colorado does not. Capacity doubling was enabled in the simulations by distributing added capacity in new mills across each state in a manner similar to its current distribution of mills. The effect of this doubling was to not only increase the amount of material that could be received at mills in the state but also to reduce by a factor of (1 -
$2^{-0.5}$ ), or approximately $30 \%{ }^{4}$, the average haul distance from base level haul distances embedded in the EBR model.

\section{Results}

\section{Evaluation of Standing Dead}

A summary of volumes and area of timberland with available salvable timber reveals that the central and northern Rocky Mountain states have the largest salvable timberland areas (Figure 1) and the largest total salvable volumes (Figure 2). Salvable timber volume, consistent with recent experience with the MPB epidemic, is highest in Montana, Colorado, Wyoming, and Idaho (Figure 2). Consistent with the assumption of our study, salvable volume shown in Figure 2 consists of standing dead volume on plots with at least $300 \mathrm{cf} / \mathrm{ac}$ of dead volume. Volumes are substantially larger on national forests compared to other owner groups and are dominated by lodgepole pine and other softwood species.

As displayed in Figures 1 and 2, the majority of timber and land affected in the 12 western states is on national forests- $88 \%$ of the total salvable volume and $84 \%$ of the total affected area. Across states, the share of the total salvable volume on national forests ranges from $61 \%$ in Nevada to $94 \%$ in Idaho and in terms of area ranges from $57 \%$ in Nevada to $91 \%$ in Idaho. The implication of these statistics is that programs that do not include national forest lands would leave large areas in the West unsalvaged.

The extent of the damage across states can be seen in Figure 3. Westwide, only $7 \%$ of all timber volume is dead and salvable, but in five states (Colorado, Montana, Idaho, Utah, and Wyoming), the salvable volume exceeds $12 \%$ of total volume and ranges up to $19 \%$. These five states contain $79 \%$ of the total dead salvable volume but only $35 \%$ of total live volume in the West. The three West Coast states (California, Oregon, and Washington) have less than 2\% of their volume in dead salvable trees.

Of the five states with the highest percentage of mortality losses, four have actual volume losses greater than 2 billion cf (Colorado, Idaho, Montana, and Wyoming). Oregon and Utah have more than 


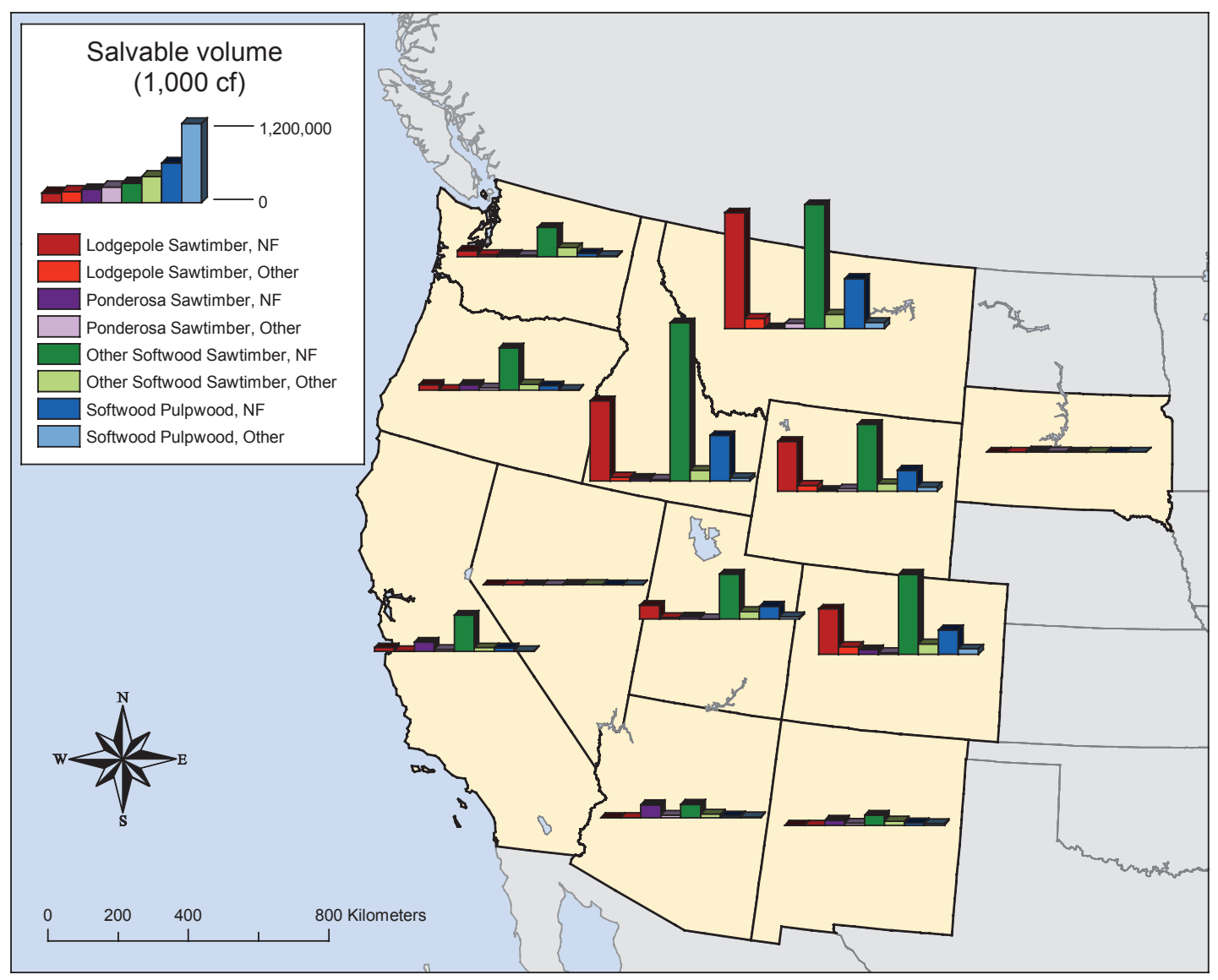

Figure 2. Salvable timber volume by state, on national forests and on nonreserved timberland owned by other groups.

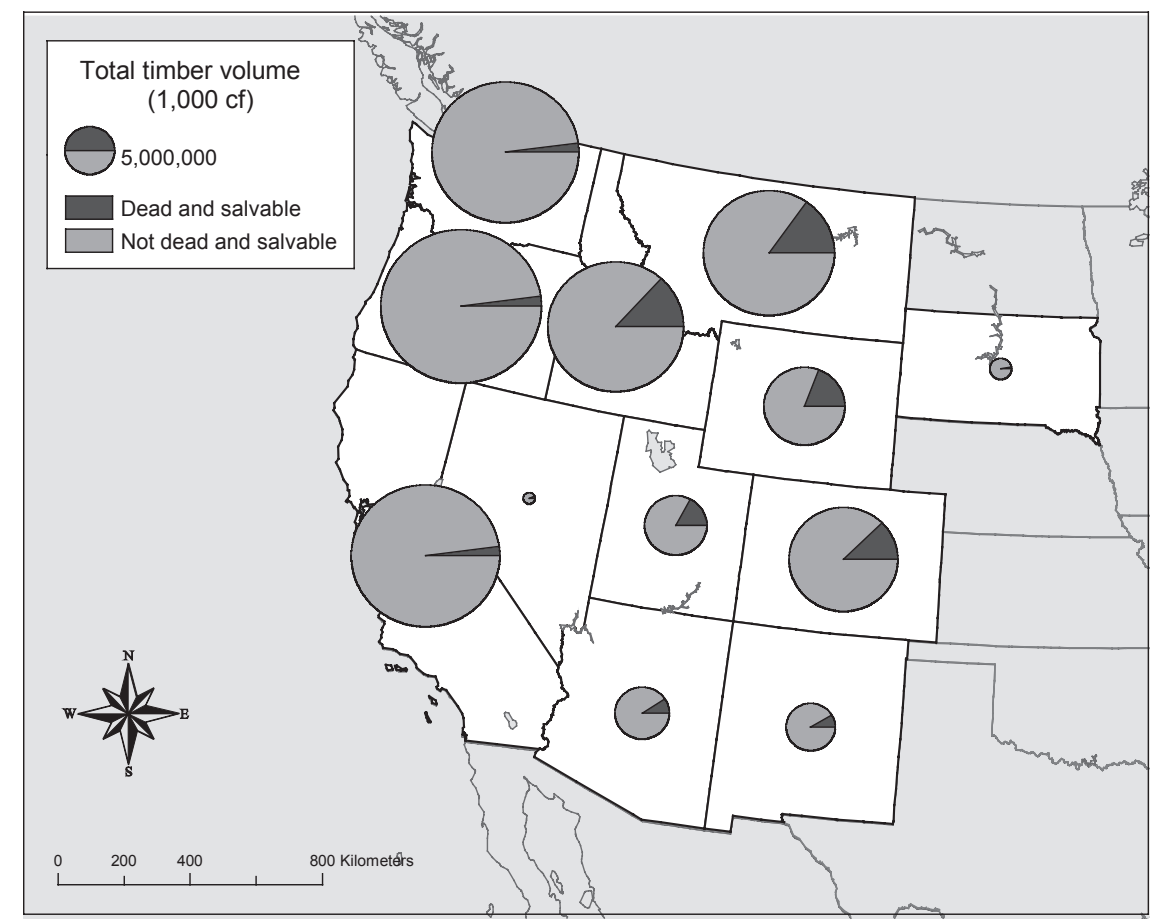

Figure 3. Proportion of total timber volume that is salvable by state.

1 billion cf of salvable volume. Of these six states with high salvable volumes, only Idaho, Oregon, and Montana have current timber processing capacity capable of absorbing large quantities of salvage.

\section{Simulations by State}

Results from the state simulations are shown in Table 3. The table reports average volumes per acre, average harvest, transport 
Table 3. Average salvage volumes, costs, revenues, and revenue-cost ratio for 20 different program sizes, ranging from $\$ 10 \mathrm{~m} /$ year to $\$ 100 \mathrm{~m} /$ year, by state and owner with current processing capacity and a continuing epidemic.

\begin{tabular}{|c|c|c|c|c|c|c|c|c|}
\hline & \multicolumn{2}{|c|}{$\begin{array}{c}\text { Average salvage volumes } \\
\text { (cf/ac) }\end{array}$} & \multicolumn{2}{|c|}{$\begin{array}{c}\text { Average salvage costs } \\
(\$ / \mathrm{ac})^{1}\end{array}$} & \multicolumn{2}{|c|}{$\begin{array}{c}\text { Average salvage revenues } \\
(\$ / a c)^{2}\end{array}$} & \multicolumn{2}{|c|}{$\begin{array}{l}\text { Average salvage program } \\
\text { revenue-cost ratio }\end{array}$} \\
\hline & All owners & $\mathrm{NF}$ & All owners & $\mathrm{NF}$ & All owners & $\mathrm{NF}$ & All owners & $\mathrm{NF}$ \\
\hline Arizona & 897 & 1,030 & 696 & 806 & 21 & 27 & 0.0 & 0.0 \\
\hline California & 1,204 & 1,291 & 638 & 700 & 1,302 & 1,461 & 2.0 & 2.1 \\
\hline Colorado & 1,310 & 1,238 & 889 & 871 & 637 & 609 & 0.7 & 0.7 \\
\hline Idaho & 1,171 & 1,230 & 656 & 803 & 1,935 & 2,727 & 2.9 & 3.4 \\
\hline Montana & 1,390 & 1,183 & 685 & 708 & 1,863 & 1,411 & 2.7 & 2.0 \\
\hline Nevada & 343 & 369 & 738 & 635 & - & - & 0.0 & 0.0 \\
\hline New Mexico & 726 & 698 & 645 & 690 & 75 & 199 & 0.1 & 0.3 \\
\hline Oregon & 1,248 & 1,233 & 435 & 548 & 760 & 1,111 & 1.8 & 2.0 \\
\hline South Dakota & 613 & 601 & 412 & 395 & 429 & 745 & 1.0 & 1.9 \\
\hline Utah & 954 & 1,022 & 719 & 769 & 8 & 10 & 0.0 & 0.0 \\
\hline Washington & 837 & 1,035 & 395 & 566 & 896 & 1,160 & 2.3 & 2.1 \\
\hline Wyoming & 1,136 & 1,119 & 1,080 & 1,162 & - & 2 & 0.0 & 0.0 \\
\hline
\end{tabular}

Table 4. Average salvage volumes, costs, revenues, and revenue-cost ratio for 20 different program sizes, ranging from $\$ 10 \mathrm{~m} /$ year to $\$ 100 \mathrm{~m} /$ year, for Colorado and Montana by owner under current capacity, doubled pulpwood capacity, and doubled all capacity.

\begin{tabular}{|c|c|c|c|c|c|c|c|c|}
\hline \multirow[b]{2}{*}{ Scenario } & \multicolumn{2}{|c|}{$\begin{array}{c}\text { Average salvage volumes } \\
(\mathrm{cf} / \mathrm{ac})\end{array}$} & \multicolumn{2}{|c|}{$\begin{array}{l}\text { Average salvage costs }{ }^{1} \\
(\$ / \mathrm{ac})\end{array}$} & \multicolumn{2}{|c|}{$\begin{array}{c}\text { Average salvage revenues }{ }^{2} \\
(\$ / a c)\end{array}$} & \multicolumn{2}{|c|}{$\begin{array}{l}\text { Average salvage } \\
\text { revenue-cost ratio }\end{array}$} \\
\hline & All owners & NF & All owners & $\mathrm{NF}$ & All owners & NF & All owners & NF \\
\hline Colorado-current capacity & 1,310 & 1,238 & 889 & 871 & 637 & 609 & 0.7 & 0.7 \\
\hline Colorado-2x pulpwood capacity & 1,310 & 1,238 & 889 & 871 & 637 & 609 & 0.7 & 0.7 \\
\hline Colorado- $2 \mathrm{x}$ all capacity & 1,550 & 1,435 & 878 & 852 & 771 & 692 & 0.9 & 0.8 \\
\hline Montana-current capacity & 1,390 & 1,183 & 685 & 708 & 1,863 & 1,411 & 2.7 & 2.0 \\
\hline Montana $-2 \mathrm{x}$ pulpwood capacity & 1,391 & 1,182 & 689 & 708 & 1,877 & 1,370 & 2.7 & 1.9 \\
\hline Montana-2x all capacity & 1,392 & 1,185 & 647 & 672 & 1,962 & 1,358 & 3.0 & 2.0 \\
\hline
\end{tabular}

${ }^{1}$ Costs include harvest, transport, and administrative costs.

${ }^{2}$ Revenues are the value of timber products at the mill gate.

${ }^{3}$ The revenue to cost ratio is the ratio of the value of delivered timber products to the costs of producing and transporting and administering the timber sale.

and administration costs, and average revenues from salvage ${ }^{5,6}$. As a way of describing whether timber salvage would generate positive or negative net revenues, we calculate the ratio of the delivered price of timber products at the mill gate to the total cost of getting the products to the mill gate- the sum of harvest, transport, and administrative costs. Revenue-cost ratios exceeding 1 indicate that salvage could be done with positive net revenues for the landowner.

Table 3 shows the results from the set of scenarios that focus on differences by state for salvage programs on either all ownerships or national forests only (assuming a continuing epidemic and current processing capacity). Volumes of salvage removed on a per acre basis in the simulations ranged from a low of $343 \mathrm{cf} / \mathrm{ac}$ in Nevada (about 12 tons/ac) to a high of $1,390 \mathrm{cf} / \mathrm{ac}$ ( 49 tons/ac) in Montana. The highest salvaged volumes per acre were found in the states with highest total and percentage salvage (Colorado, Idaho, Montana, and Wyoming), as well as California and Oregon.

Salvage generates positive net revenues in Idaho, Montana, Washington, Oregon, California, and South Dakota (Table 3). These are states with relatively vigorous timber markets relative to the size of the salvage being removed. States where salvage generates revenues that are on average less than salvage costs (includes removal, transport, and administration) - that is, timber stumpage values would be less than or equal to zero-include Colorado and Wyoming, which have large proportions of salvable volume, and Nevada. In both Wyoming and Nevada, prices for delivered salvage timber products are driven so low by salvage programs that they approach zero, also indicating zero stumpage value, while in Utah and Arizona, prices drop nearly to zero. The zero and near zero ratio of delivered product revenue to cost occurs because their costs per acre of salvage are high and their markets are weak. For Wyoming and Colorado, relatively high volumes per acre removed lead to quick saturation of available markets even when total acres harvested is small (Table 3).

\section{Simulations of Expansion of Processing Capacity}

Results from the scenarios evaluating the addition of processing capacity are shown in Table 4. Simulating the expansion of mill capacity to absorb salvage, done only for Colorado and Montana, illustrates several potential effects of enhanced demand on salvage opportunities. Expansions in mill capacities are smaller when only pulpwood consuming mills are considered, but the direction of effect is similar to that shown for the scenario when both sawtimber and pulpwood consuming mills double in their capacity (and increase in the overall landscape density). The smaller benefits of expanding pulpwood capacities are because such timber products have relatively low value relative to their harvest, transport, and administration costs. Policies or programs that are designed to increase the use of wood for energy-whose feasibility we do not directly evaluate here-would likely be directed to increasing the market for biomass, which coincides with the current pulpwood market. The sawtimber plus pulpwood expansion could occur if a policy enhanced profitability at biomass use facilities and if privately financed expansion of sawtimber processing capacity occurred because biomass harvests would remove salvable sawtimber as well. 
Table 5. Average salvage volumes, costs, revenues and revenue-cost ratio for 20 different program sizes, ranging from $\$ 10 \mathrm{~m} /$ year to $\$ 100 \mathrm{~m} /$ year, West-wide by owner under both a continuing epidemic and an ending epidemic.

\begin{tabular}{|c|c|c|c|c|c|c|c|c|}
\hline \multirow[b]{2}{*}{ Scenario } & \multicolumn{2}{|c|}{$\begin{array}{l}\text { Average salvage volumes } \\
\text { (cf/ac) }\end{array}$} & \multicolumn{2}{|c|}{$\begin{array}{l}\text { Average salvage costs }{ }^{1} \\
(\$ / \mathrm{ac})\end{array}$} & \multicolumn{2}{|c|}{$\begin{array}{l}\text { Average salvage } \\
\text { revenues }^{2}(\$ / \mathrm{ac})\end{array}$} & \multicolumn{2}{|c|}{$\begin{array}{l}\text { Average salvage } \\
\text { revenue-cost ratio }\end{array}$} \\
\hline & All owners & NF & All owners & NF & All owners & $\mathrm{NF}$ & All owners & $\mathrm{NF}$ \\
\hline Westwide-epidemic continues & 904 & 1,005 & 494 & 611 & 779 & 582 & 1.6 & 1.0 \\
\hline Westwide-epidemic stops & 970 & 1,020 & 648 & 700 & 906 & 960 & 1.4 & 1.4 \\
\hline
\end{tabular}

Timber processing capacity is a constraint in the EBR model, even though timber can be shipped greater distances when capacity is limiting so that increasing capacity is expected to change the outcome of the simulations. Increasing the density of mills across the landscape will reduce transportation costs. The average effect of the density increase was to reduce salvage costs (which include transportation costs) by 1 and $6 \%$ for Colorado and Montana, respectively, when all owners are considered, and by 2 and 5\% for these states, respectively, when only national forests are modeled (Table 4). Revenues per acre with increased processing capacity are more strongly affected than costs, raising them by $21 \%$ for Colorado and $5 \%$ for Montana when all owners are considered and by $14 \%$ for Colorado when national forests only are considered. Revenues per acre fall slightly for Montana, on the other hand, by about $1 \%$ when only national forests are modeled because salvage activity is more heavily concentrated in places where timber prices are driven down somewhat by higher overall supply to the market. The fall in revenues is accompanied by a larger fall in costs per acre, however, increasing the ratio of revenues to cost for national forests in Montana under this scenario. The ratio of revenues to costs increases by about $15 \%$ for Colorado and by $29 \%$ for Montana when all owners are considered but by only 20 and 7\%, respectively, when such programs are conducted only on national forests. When capacity was allowed to double ${ }^{7}$ for both sawtimber and pulpwood consuming mills in Colorado and Montana, private and other public shares increased slightly, by $2 \%$ for Colorado and 3\% for Montana (Table 4).

\section{Simulations of Continuing and Ending Epidemics}

The simulation of a Westwide salvage program that did not face a net increase in available salvable timber, consistent with a beetle epidemic that has reached its effective end, is reported in Table 5 and in Figures 4 and 5. Assuming the epidemic ends reduces the revenue-to-cost ratio Westwide for all owners but increases it for national forests.

For all timberlands combined, salvage under the largest spending program ( $\$ 1$ billion/year) is about 1.3 million ac per year with an ending epidemic (i.e., no net increase in salvable timberland; Figure $4 \mathrm{~B})$ versus more than 1.7 million ac/year under an assumed continuing epidemic (Figure 4A). The main reason for the higher salvage rates for a given level of spending shown in Figure $4 \mathrm{~B}$ as compared to Figure 4A is because new salvage opportunities (locations with positive net revenues from salvage) emerge in places with higher expected net revenues. Furthermore, the smaller area available to salvage under the no-net-increase scenario diversifies where timber is salvaged. For the largest spending programs, almost all salvage occurs in California, Idaho, Montana, Oregon, and Washington under the base case assumption of a net increase in salvable timber over time. When there is no net increase in salvable timber, salvage in the largest programs additionally moves into Colorado, New Mexico, and Utah. The effect of this diversification is to increase average salvage costs by $31 \%$ and to increase average revenues per acre by only $16 \%$, resulting in a drop in the revenue-to-cost ratio shown in Table 5.

The case of national forests only (Figure 5) produces a similar spatial pattern, with an even stronger move toward interior West states in larger programs if an ending epidemic is simulated. The effects on salvage from an ending epidemic are also similar, increasing average salvage volumes, costs, and revenues. Average revenues increase by $65 \%$ on a per acre basis while average costs increased by only $15 \%$, resulting in a rise in the revenue-to-cost ratio (Table 5), which is opposite of the all-owner case. The larger percentage increase in revenues from this simulation compared to the all-owner simulation is because the all-owner simulation harvests stands with both lower revenue and even lower-cost privately owned stands.

In places where large salvable volumes exist, a continuing epidemic that leads to increases in salvage will depress prices. These increases in salvage tend to be in states with weak timber markets in the interior West, which experience significant negative price effects from a large-scale salvage program. When the area and volume of such salvable timber is steady, as could occur when the epidemic is ending, these negative price impacts are dampened, yielding a higher ratio of revenue to costs, partly because lower total salvage volumes enter markets and prices are less depressed.

In a program that could occur on all lands, the share of timber volume removed from private and other public lands varies by geography and by scenario (Figure 6). Nevada, with very low volumes of salvable timber, had no private or other public volume removed. For the remaining states, the average percentage removed from private and other public lands averaged, across all simulations, from $4 \%$ in Colorado to $57 \%$ in Washington.

Westwide, $37 \%$ of the salvage occurred on private and other public land when the epidemic was assumed to continue, but this dropped to only $12 \%$ when the epidemic was assumed to have ended. This reflects the fact that timber salvaged from private and other public land is preferred but quickly exhausted compared to national forest salvage. In part this preference is due to our assumption that harvest costs on national forest lands were higher than on private lands.

\section{Discussion}

Epidemic bark beetle populations have resulted in widespread mortality of pines in the western United States, most recently affecting lodgepole pine in the northern Rocky Mountains. The existence of substantial salvable timber in high-mortality locations creates opportunities for revenues on both public and private lands. We used existing FIA plots to quantify salvable timber Westwide. We used the EBR simulation model to quantify the costs of salvage and 

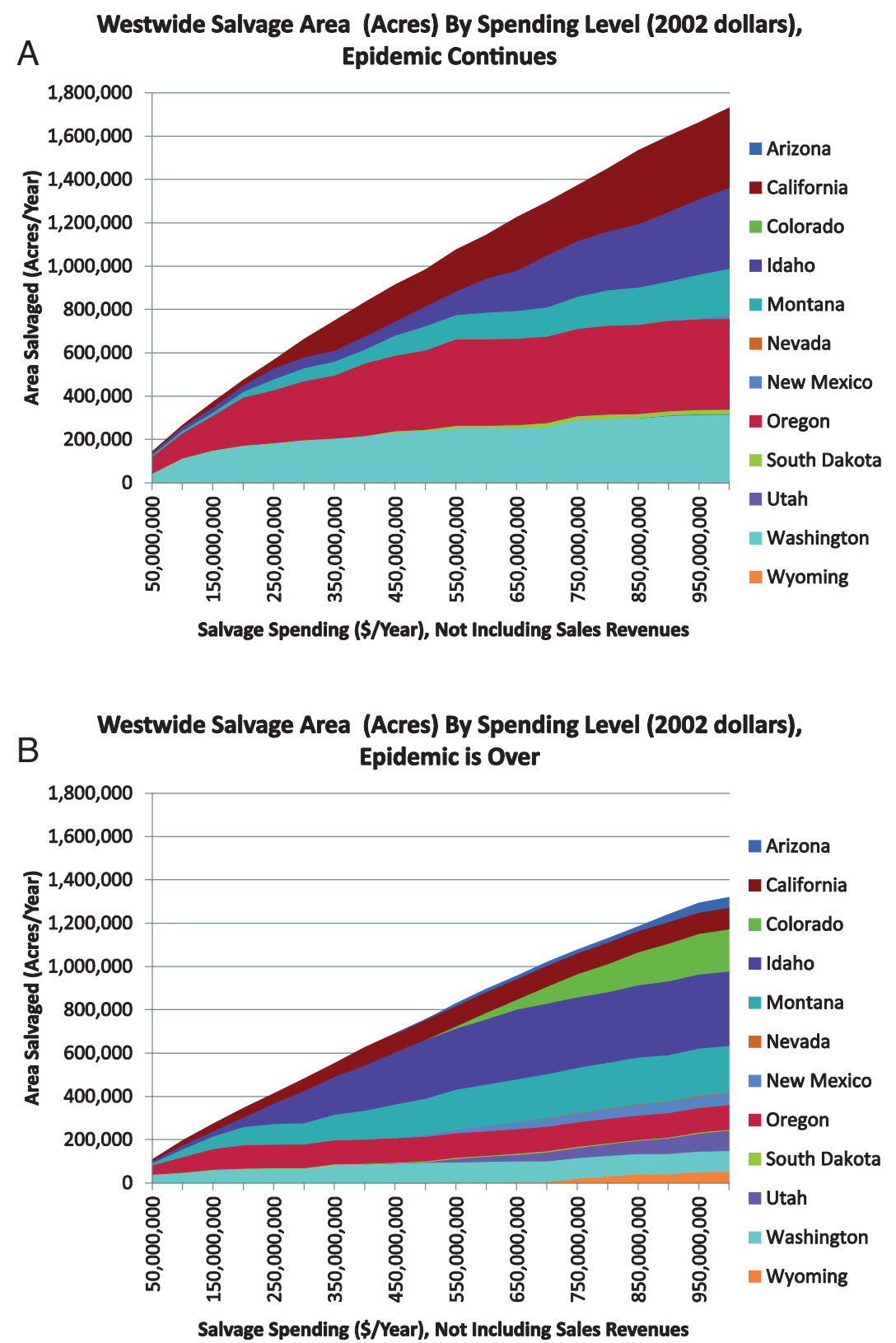

Figure 4. Area of timber salvage by state, in a simulation of a Westwide salvage program across program sizes ranging from $\$ 50$ million/year to $\$ 1,000$ million/year, all owners, under (A) the base case $2 \%$ per year of healthy timberland moving into salvable timberland (epidemic continues), (B) no net increase in healthy timberland moving into salvable timberland (epidemic is over).

the potential revenues available on salvage. The model accounted for the negative market effects that significant timber volume salvage would have on prices (e.g., Holmes 1991, Prestemon and Holmes 2000) and the degradation that such timber is assessed on sale. With this information, we described places of potential priority for salvage extraction, based on expected net revenues. Unfortunately, insufficient information exists about the causes of tree death on FIA plots, so the assessment of potential net revenues from salvage focuses on all salvable timber, regardless of whether the salvable trees are in areas of active pine beetle outbreak.

We note six implications from our study. First, dead salvable timber lies disproportionately on national forest lands. Five states (Colorado, Wyoming, Montana, Idaho, and Utah) have $75 \%$ of all dead salvable timber Westwide, with most of this on national forests. On national forests, the most recent data indicate that salvage volume sold, totaling 352 million bf in fiscal year 2011, represents less than one-fifth of all timber sold, (USDA Forest Service 2011a); our analyses show that much more is still available.

Second, salvage in California, Oregon, Washington, Idaho, South Dakota, and Montana could generate positive net revenues, on both private and public lands, across a wide range of potential salvage intensities. The greater the salvage intensity across these states, the larger the net revenues generated.

Third, our simulations show that salvage would not generate positive net revenues in the interior western states of Arizona, New Mexico, Utah, Colorado, Nevada, or Wyoming. However, salvaging an acre of timber in Colorado is not as much of a money-losing proposition as it would be in the other interior states.

Fourth, it is possible that an expansion of timber processing capacity (resulting in an increase in timber demand) could help 

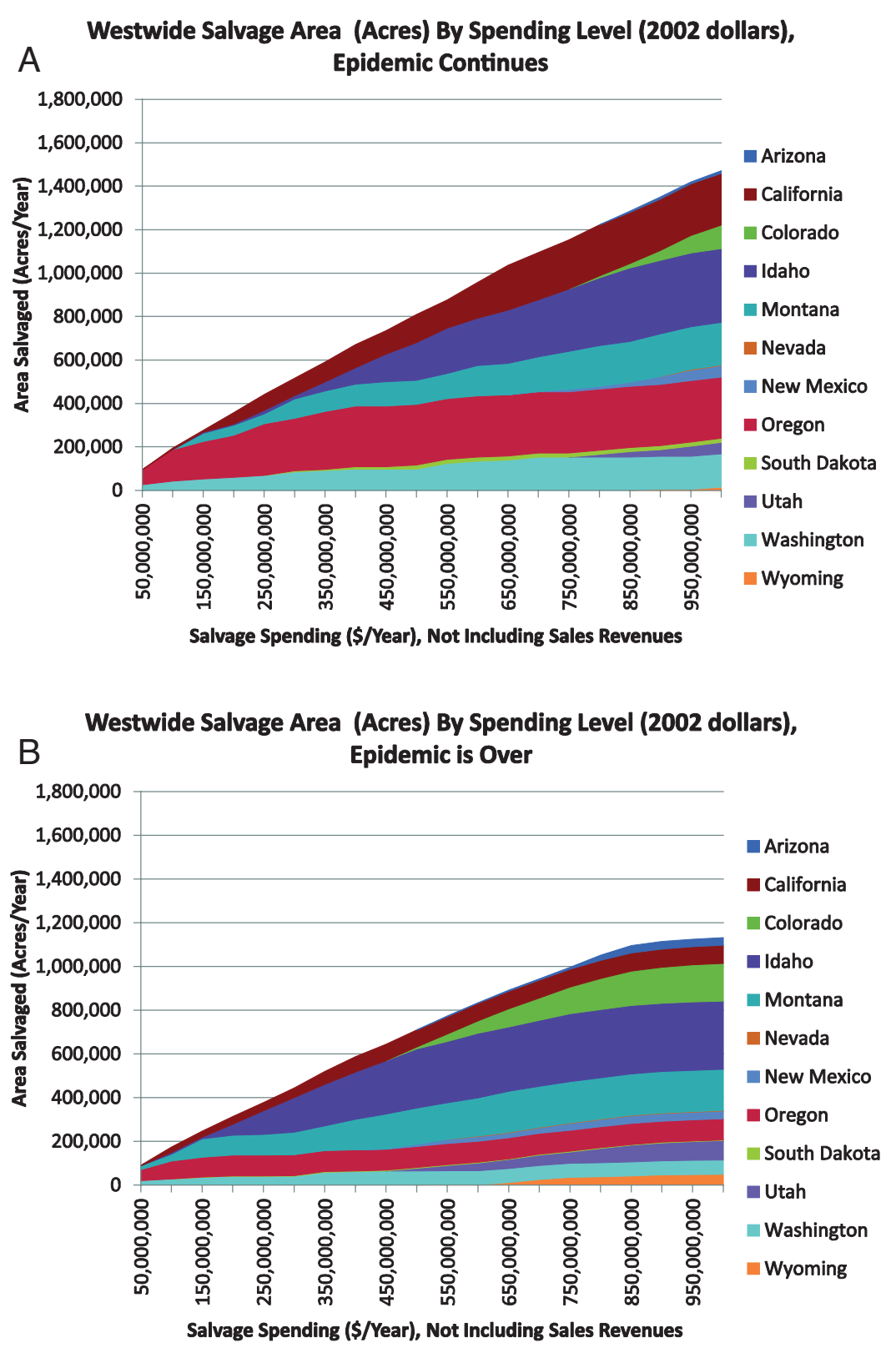

Figure 5. Area of timber salvage by state in a simulation of a Westwide salvage program across program sizes ranging from $\$ 50$ million/year to $\$ 1,000$ million/year, for national forests only, under (A) the base case $2 \%$ per year of healthy timberland moving into salvable timberland (epidemic continues), (B) no net increase in healthy timberland moving into salvable timberland (epidemic is over).

alleviate some of the financial losses for owners of dead standing timber in these dry interior western states. Such an expansion could come about as a result of government programs to encourage new demand. Our examination of a doubling of capacity was limited to two states heavily affected by the current MPB epidemic: Colorado and Montana. Assuming doubled capacity in wood consuming mills, net revenues generated by salvage are slightly higher in both states. However, states with less robust markets, such as Colorado and Wyoming, are also faced with the prospect of both costly harvests and immediately saturated timber markets upon harvest. Such increased salvage would, furthermore, negatively impact owners of green timber who are seeking to harvest by forcing down market prices. It is possible that efforts to "grow the pie" by encouraging expanded market opportunities-including traditional forest products and perhaps new bioenergy uses - could mitigate some of the negative market price effects of salvage programs. Such market ex- pansions, however, would have to be very large, resulting in timber prices that are higher than today's prices, to limit losses to landowners conducting the salvage harvests. Further, overall higher salvage rates, regardless of directed government efforts to encourage salvage, face an immediate challenge of weak timber markets, a consequence especially of construction market contraction since the mid-2000s (Howard and Westby 2009, Keegan et al. 2011).

Fifth, under a scenario where the epidemic is ending, available salvage is more quickly eliminated in the highest net revenue states, making larger programs move to the loss-generating states of the southern interior West. A continuing epidemic would keep most salvage on the West Coast and in Idaho and Montana. It is not clear whether the current MPB outbreak will continue to expand or whether it is reaching its apex. Scenarios run to evaluate the effects of a $\mathrm{MPB}$ control program to suppress a continuing epidemic versus an ending epidemic were run Westwide at $\$ 50$ million/year program 


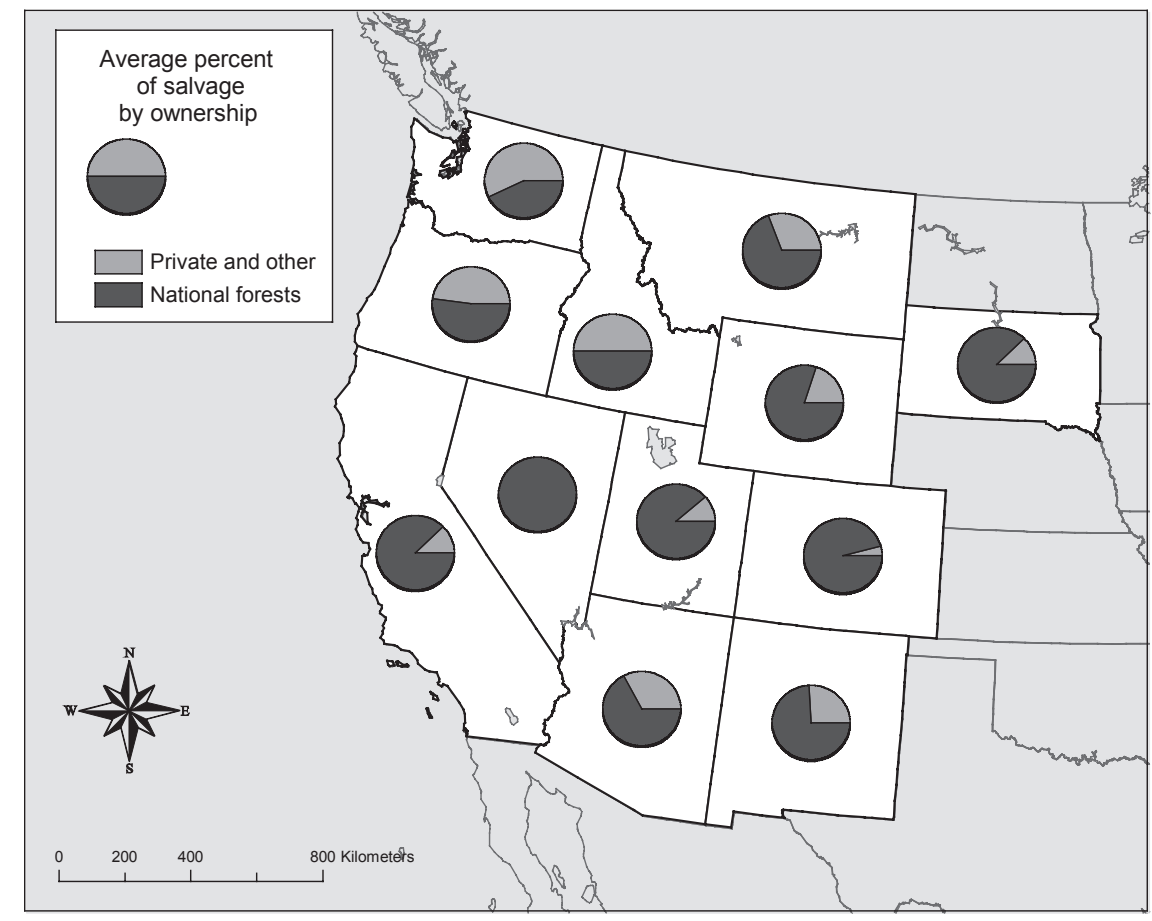

Figure 6. Proportion of salvage volume removed by owner group under a simulation allowing for choice between private and other public and national forest managed lands.

increments, up to $\$ 1$ billion/year. Regardless of whether salvable timberland increases over time, salvage revenue-to-cost ratios were typically highest in California, Oregon, Washington, Idaho, and Montana. In short, rapidly expanding areas and volumes of salvable timber, particularly in states with robust timber markets (Idaho, Montana), could be salvaged profitably. Much of that salvage could and likely would occur on private lands.

Sixth, private and other public lands tend to have more profitably salvaged timberland when compared to national forests, even though private and other public salvable timber accounts for only $21 \%$ of current standing salvable volume Westwide. We must reiterate, however, that profits from private salvage are taxed, so not all of such revenues are ultimately captured by private landowners. Smaller efforts to encourage salvage could be successful on these lands. Programs favoring private and other public salvage would likely be most successful at removing salvage in states with significant processing capacity and stronger timber prices, such as California, Oregon, Washington, Idaho, and Montana. On the other hand, it is in these states where the economic incentives for such salvage are apparently already present due to higher overall timber prices. Locations with higher prices are more likely to have stands where salvage revenues can exceed salvage costs. As Holmes (1991) explained, standing dead timber inventory has zero opportunity cost, so as long as it has nonzero stumpage value, it can become part of the supply of marketable timber.

Finally, we note that our analyses evaluated only the costs and revenues generated by salvage harvest operations. Other benefits and/or costs of salvage harvesting not considered here- e.g., the potential to alter subsequent wildfire activity (e.g., Fraver et al. 2011, Klutsch et al. 2011, Simard et al. 2011) or enhance jobs and income opportunities (Abt et al. 2011) — could contribute to decisions to undertake salvage programs on any lands, private or public.

The USDA Forest Service, private landowners, forestry professionals, and the general public have been concerned for at least the last decade about the extraordinary scale of the mountain pine beetle epidemic and its attendant aesthetic and economic impacts as well as the potential dangers it poses to the public. Our results show that whether the current epidemic proceeds apace or whether it stops, whether new markets emerge for salvaged timber or not, the basic geographical contours of the economic feasibility of salvage are not substantially altered: places where timber product markets are strong are likely to have profitable salvage, while places where product markets are weak would need sizable public expenditures to achieve appreciable reductions in the amount of dead standing timber. Nonetheless, this study provides a first approximation of the net revenues obtainable from salvaging beetle-killed timber across the West in the wake of the current epidemic. Additional advances in our understanding could be made with more accurate information on how the rate of wood deterioration varies across forests of the West, how advances in lumber recovery technology could translate into higher beetle-killed log values at mill gates, and how higher wood prices brought about by a rising construction market or new uses for wood in the energy sector would enable higher net revenues from salvage in the West.

\section{Endnotes}

1. As indicated in Abt et al. (2011), the $\$ 200 /$ ac fixed cost for salvage on government lands accounts for sale preparation, environmental analysis, and harvest monitoring. On nongovernment timberlands, this cost was set at $\$ 100 / \mathrm{ac}$.

2. Boundaries can be viewed at//landfire.cr.usgs.gov/viewer/.

3. The $2 \%$ rate of expansion in salvable timberland is our estimate of the rate of increase in the area of timberland affected by the ongoing MPB epidemic. This expansion rate is consistent with an estimate that an average of $1.8 \%$ of the total area of lodgepole pine forest in the western United States experienced mortality annually between 1997 and 2010 due to MPB. This estimate is based on mortality area estimates from Meddens et al. (2012) and lodgepole pine forest area from Smith et al. (2009).

4. This emerges from a principle relating nearest neighbor distance to population densities (Blackith 1958).

5. We do not report a benefit to cost ratio because we do not calculate benefits in terms of economic surplus. 
6. Generally, smaller programs generate the highest net revenues per acre, as timber prices are higher and costs are generally lower. The EBR model selects those locations on the landscape to salvage first based on expected net revenues.

7. The EBR model does not have an "endogenous" mill capacity feature, such as Tobin's profit-driven Q ratio. Ince et al. (2008), when analyzing the timber product output implications of wildfire hazard reduction treatments in the western United States, described how capacity that is endogenous in this way could encourage expanded demand. To understand the effect of expanded salvage demand that might result from enhanced profits for timber processors in this study, we conducted this sensitivity analysis.

\section{Literature Cited}

ABT, K.L., And J.P. Prestemon. 2006. Timber markets and fire-related fuel treatments in the western US. Nat. Res. Mod. 19(1):15-43.

Abt, K.L., J.P. Prestemon, K. Skog, R.J. Barbour, M. Hemstrom, and R.J. HugGetT JR. 2011. Simulations of alternative mechanical fuel treatment programs on western timberland. USDA For. Serv., Res. Pap. RP-SRS-52. 10 p.

Backsen, J.C., AND B. Howell. 2013. Comparing aerial detection and photo interpretation for conducting forest health surveys. West. J. Appl. For. 28(1):3-8.

Barbour, R.J., X. Zhou, And J.P. Prestemon. 2008. Timber product output implications of a national program of mechanical fuel treatments applied on government timberland in the Western States of US. For. Pol. Econ. 10(6):374-385.

Bechtold, W.A., AND P.L. PAtterson. 2005. The enhanced forest inventory and analysis program - National sampling design and estimation procedures. USDA For. Serv., Gen. Tech. Rep. SRS-80. 85 p.

BLACKITH, R.E. 1958. Nearest-neighbor distance measurements for the estimation of animal populations. Ecology 39(1):147-150.

Chapman, T.B., T.T. Veblen, and T. Schoennagel. 2012. Spatiotemporal patterns of mountain pine beetle activity in the southern Rocky Mountains. Ecology 93(10):2175-2185.

Fahey, T.D., T.A. Snellgrove, and M.E. Plank. 1986. Changes in product recovery between live and dead lodgepole pine: A compendium. USDA For. Serv., Res. Pap. PNW-RP-353. 32 p.

Fraver, S., T. Jain, J.B. Bradford, A.W. D’Amato, D. Kastendick, B. Palik, D. SHINNEMAN, AND J. STANOVICK. 2011. The efficacy of salvage logging in reducing subsequent fire severity in conifer-dominated forests of Minnesota, USA. Ecol. Appl. 21(6):1895-1901.

Holmes, T.P. 1991. Price and welfare effects of catastrophic forest damage from southern pine beetle epidemics. For. Sci. 37(2):500-516.

HOWARD, J.L., AND R. WESTBY. 2009. US forest products annual market review and prospects, 2005-2009. USDA For. Serv., Res. Note FPL-RN-0313. 9 p.

HugGetT, R.J. JR., K.L. ABT, AND W. SHEPPERD. 2008. Efficacy of mechanical fuel treatments for reducing wildfire hazard. For. Pol. Econ. 10(6):408-414.

Ince, P.J., H. Spelter, K. Skog, A. Kramp, And D.P. DyKstra. 2008. Market impacts of hypothetical fuel treatment thinning programs on federal lands in the western United States. For. Pol. Econ. 10(6):363-372.

Keegan, C.E., C.B. Sorenson, T.A. Morgan, J.M. Daniels, and S.W. Hayes. Impact of the great recession and housing collapse on the forest products industry in the western United States. For. Prod. J. 61(8):625-634.
Klutsch, J.G., M.A. Battaglia, D.R. West, S.L. Costello, and J.F. Negrón. 2011. Evaluating potential fire behavior in lodgepole pine-dominated forests after a mountain pine beetle epidemic in north-central Colorado. West. J. Appl. For. 26(3):101-109.

LANDFIRE. 2010. LANDFIRE distribution site. Available online at www. landfire.gov/index.php; last accessed Oct. 18, 2010.

Lowell, E.C., S.A. Willits, AND R.L. Krahmer. 1992. Deterioration of fire-killed and fire-damaged timber in the Western United States. USDA For. Serv., Gen. Tech. Rep. PNW-GTR-292. 27 p.

Meddens, A.J.H., J.A. Hicke, AND C.A. Ferguson. 2012. Spatiotemporal patterns of observed bark beetle-caused tree mortality in British Columbia and the western United States. Ecol. Appl. 22(7):1876-1891.

Patriquin, M.N., A.M. Wellstead, AND W.A. White. 2007. Beetles, trees, and people: Regional economic impact sensitivity and policy considerations related to the mountain pine beetle infestation in British Columbia, Canada. For. Pol. Econ. 9(8):938-946.

Prestemon, J.P., K.L. AbT, And R.J. Barbour. 2012. Quantifying the net economic benefits of mechanical wildfire hazard treatments on timberlands of the western United States. For. Pol. Econ. 21:44-53.

Prestemon, J.P., K.L. AbT, And R.J. Huggett JR. 2008. Market impacts of a multiyear mechanical fuel treatment program in the US. For. Pol. Econ. 10(6):386-399.

Prestemon, J.P., And T.P. Holmes. 2000. Timber price dynamics following a natural catastrophe. Am. J. Agric. Econ. 82(1):145-160.

Prestemon, J.P., And T.P. Holmes. 2004. Market dynamics and optimal timber salvage after a natural catastrophe. For. Sci. 50(4):495-511.

Prestemon, J.P., D.N. Wear, T.P. Holmes, F. Stewart. 2006. Wildfire, timber salvage, and the economics of expediency. For. Pol. Econ. 8(3):312-322.

SAmuelson, P. 1952. Spatial price equilibrium and linear programming. Am. Econ. Rev. 42(3):283-303

Simard, M., W.H. Romme, J.M. Griffin, And M.G. Turner. 2011. Do mountain pine beetle outbreaks change the probability of active crown fire in lodgepole pine forests? Ecol. Monogr. 81(1):3-24.

Smith, W.B., P.D. Miles, C.H. Perry, and S.A. Pugh. 2009. Forest resources of the United States, 2007. USDA For. Serv., Gen. Tech. Rep. GTR-WO-78. $336 \mathrm{p}$.

Spelter, H., D. McKeever, AND D. Toth. 2009. Profile 2009: Softwood sawmills in the United States and Canada. USDA For. Serv., Res. Pap. RP-FPL-659. 55 p.

TAKAYAma, T., AND G.G. JudGE. 1964. Equilibrium among spatially separated markets: A reformulation. Econometrica 32(4):510-523.

USDA Forest SERVICE. 2011a. PTSAR (Administrative Unit Summary) PTSR202S version FY Awarded w/Offer, Cumulative FY 2011 Q1 to FY 2011 Q4 as of 2011 4th quarter. Available online at www.fs.fed.us/ forestmanagement/documents/ptsar/2011/2011_Q1-Q4_PTSR202S.pdf; last accessed July 31, 2012.

USDA FOREST SERVICE. 2011b. Western bark beetle strategy: Human safety, recovery and resiliency. Available online at www.fs.fed.us/publications/ bark-beetle/bark-beetle-strategy-appendices.pdf; last accessed Feb. 8, 2013.

Vysea, A., C. Ferguson, D.J. Huggard, J. Roach, and B. Zimonick. 2009. Regeneration beneath lodgepole pine dominated stands attacked or threatened by the mountain pine beetle in the south central Interior, British Columbia. For Ecol. Manage. 258(Suppl.):S36-S43. 